\title{
Effect of Phosphorus and Bio-fertilizers on Yield, Nutrient Content and Uptake of Urban [Vigna mungo (l.) Hepper]
}

\author{
Maya Yadav', S.S. Yadav, Sunil Kumar ${ }^{2 *}$, Hansa Kumari Yadav and Pradip Tripura ${ }^{3}$ \\ ${ }^{1}$ Department of Agronomy, S.K.N. college of Agriculture, SKNAU Jobner- 303329 \\ ${ }^{2}$ Department of Agronomy, IAS, BHU, Varanasi-221 005, India \\ ${ }^{3}$ Department of Soil Science and Agricultural Chemistry JAU, Junagharh, India \\ *Corresponding author
}

\begin{tabular}{l} 
Ke y w or d s \\
Phosphorus, \\
Phosphorus \\
Solubilizing bacteria, \\
Vesicular arbuscular \\
mycorrhiza, \\
Nutrient uptake and \\
yield \\
\hline Article Info \\
Accepted: \\
19 April 2017 \\
Available Online: \\
10 May 2017
\end{tabular}

\section{A B S T R A C T}

A field experiment was conducted during Khari season of 2014 on loamy sand soil to study the effect of phosphorus levels and bio-fertilizers on productivity, nutrient content and uptake of urban. Experiment consisted of four treatments of phosphorus levels $(0,20,40$ and $60 \mathrm{~kg} / \mathrm{ha})$ and four treatments of bio-fertilizers (control, PSB, VAM and PSB + VAM) thereby making sixteen treatment combinations tested in randomized block design with three replications. Result indicated that application of phosphorus up to $40 \mathrm{~kg} / \mathrm{ha}$ significantly increased grain and straw yield, net returns, protein content in grain, nitrogen, phosphorus and potassium concentration in grain and straw and total uptake of nitrogen, phosphorus and potassium over preceding levels and remained at par with 60 $\mathrm{kg} / \mathrm{ha}$. Whereas, raising the level of phosphorus from 0 to $20 \mathrm{~kg} / \mathrm{ha}$ registered the highest agronomic efficiency, apparent recovery and physiological efficiency of phosphorus after that, it showed significant decline up to $60 \mathrm{~kg} / \mathrm{ha}$. Combined inoculation of seed and soil with PSB + VAM significantly increased the grain and straw yield, net returns, nitrogen, phosphorus and potassium concentration in grain and straw, their total uptake as well as protein content in grain and available phosphorus in soil after crop harvest over PSB, VAM and control, whereas, the highest agronomic efficiency and apparent recovery of P recorded under PSB + VAM inoculation and phvsiological efficiencv under control.

\section{Introduction}

Pulses are the main source of dietary protein particularly for vegetarians and contribute about 14 per cent of the total protein of average Indian diet. Urdbean [Vigna mungo (L.) Hepper] is among the major pulses grown throughout the country during both in summer and rainy season. It is a self pollinated leguminous crop containing $24 \%$ protein. The duration of the crop is very short; it fits well in various multiple and intercropping systems. After removing pods, its plant may be used as good quality green or dry fodder or green manure. Being a legume, it also enriches soil by fixing atmospheric nitrogen. Phosphorus is a universally deficient plant nutrient in most of the soils of Rajasthan, particular in light textured soils. Application of phosphorus to pulse crop has been found very effective and 
called as master key element for increasing yield. its play a vital role in growth and development of roots, phosphorus is also necessary for growth of Rhizobium bacteria responsible for biological fixation of $\mathrm{N}$ to increase the efficiency of pulses as soil renovator and serves the dual purpose of increasing yield of main as well as succeeding crop. An adequate supply of phosphorus has been reported good for better growth, yield, quality and enormous nodule formation in legumes (Sammauria et al., 2009). It acts as a structural component of membrane system of cells, chloroplasts and mitochondria. It is a constituent of energy phosphates like ADP and ATP, nucleic acids (DNA and RNA), nucleo proteins, purines, pyrimidine, nucleotides and several coenzymes. About 93-99 per cent of the total phosphorus is insoluble and hence directly not available to plants. Inoculation of $\mathrm{P}$ solubilizing microorganisms in the rhizosphere of crop and soil increases the availability of $\mathrm{P}$ from insoluble sources of phosphate, desorption of fixed phosphates and also increases the efficiency of phosphatic fertilizers through secreting acidic substances (Gaur, 1991). Symbiosis between plant roots and certain soil fungi e.g. Vesicular Arbuscular Mycorrhiza (VAM) plays an important role in phosphorus cycling and its uptake by plants (Biswas et al.,(2001). These symbiotic microorganisms have extensive mycelial network and can increase the transport of other mineral elements such as zinc and copper. VAM fungi can play an important role in enhancing $\mathrm{P}$ availability to plants in deficient soils and can save P-fertilizer by $25-30 \%$ (Somani et al., 1990).

\section{Materials and Methods}

A field experiment was conducted during kharif season of 2014 at the Agronomy Farm, S.K.N. College of Agriculture, Jobner (Rajasthan). Soil of the experimental field was loamy sand in texture with alkaline in reaction $(\mathrm{pH}$ 8.2), low in organic carbon $(0.14 \%)$ and available nitrogen $(137.4 \mathrm{~kg} / \mathrm{ha})$, medium in available phosphorus $(16.2 \mathrm{~kg} / \mathrm{ha})$ and potassium (154.2 kg/ha). Experiment was laid out in randomized block design with sixteen treatment combinations comprised of four phosphorus levels $(0,20,40$ and 60 $\mathrm{kg} / \mathrm{ha}$ ) and four treatments of bio-fertilizers viz., (control, PSB, VAM and PSB + VAM). The urdbean variety T-9 was sown using seed rate $15 \mathrm{~kg} / \mathrm{ha}$ with a row spacing of $30 \mathrm{~cm}$ at the depth of $4-5 \mathrm{~cm}$. Seeds were treated with PSB culture using three packets (200 g each) for $15 \mathrm{~kg}$ of seed of urdbean needed for sowing for one hectare and VAM was applied as per treatments to the open furrow using field soil to bulk the carrier. Uniform dose of nitrogen $25 \mathrm{~kg} / \mathrm{ha}$ was applied to all the plots by adjusting the nitrogen supplied by DAP and remaining through urea at the time of sowing. Whereas, phosphorus was applied as per treatments through DAP. N concentration was determined by modified Kjeldahl method while total $\mathrm{P}$ determined using sulphuricnitric-perchloric acid digest procedure. $\mathrm{K}$ was determined by tri acid digestion procedure on flame photometer.

\section{Results and Discussion}

\section{Effect of phosphorus levels}

Successive increase in phosphorus levels significantly increased number of pods/plant, number of grains/pod, test weight, grain yield, straw yield and biological yield up to 40 $\mathrm{kg} / \mathrm{ha}$, which was comparable with application of highest level of $60 \mathrm{~kg} / \mathrm{ha}$ and no significant effect was observed on harvest index (Table 1). The increase in grain yield with $60 \mathrm{~kg} / \mathrm{ha}$ was 13.9 and $51.2 \%$ over 20 $\mathrm{kg} / \mathrm{ha}$ and control, respectively. This could be attributed due to better root proliferation, higher root development, increased availability and uptake of nutrients, energy transformation and metabolic processes in plant. 
Table.1 Effect of phosphorus fertilization and bio-fertilizers on yield attributing characters, grain, straw, biological yield, harvest index and net returns

\begin{tabular}{|c|c|c|c|c|c|c|c|c|}
\hline Treatments & $\begin{array}{l}\text { Number of } \\
\text { pods/plant }\end{array}$ & $\begin{array}{l}\text { Number of } \\
\text { grains/pod }\end{array}$ & $\begin{array}{c}\text { Test } \\
\text { weight } \\
(\mathrm{g})\end{array}$ & $\begin{array}{c}\text { Grain } \\
\text { yield } \\
\text { (kg/ha) }\end{array}$ & $\begin{array}{c}\text { Straw } \\
\text { yield } \\
\text { (kg/ha) }\end{array}$ & $\begin{array}{c}\text { Biological } \\
\text { yield } \\
\text { (kg/ha) }\end{array}$ & $\begin{array}{c}\text { Harvest } \\
\text { index }(\%)\end{array}$ & $\begin{array}{c}\text { Net } \\
\text { returns } \\
\text { (Rs/ha) }\end{array}$ \\
\hline \multicolumn{9}{|c|}{ A. Phosphorus levels (kg/ha) } \\
\hline Control & 16.60 & 5.90 & 34.20 & 784 & 1561 & 2345 & 33.46 & 27489 \\
\hline 20 & 22.70 & 7.10 & 37.10 & 1041 & 2062 & 3103 & 33.93 & 41021 \\
\hline 40 & 27.20 & 7.80 & 38.60 & 1160 & 2340 & 3500 & 33.17 & 47003 \\
\hline 60 & 28.80 & 8.20 & 39.85 & 1186 & 2394 & 3580 & 33.27 & 47458 \\
\hline $\mathrm{SEm} \pm$ & 0.62 & 0.18 & 0.93 & 25 & 49 & 78 & 1.13 & 1113 \\
\hline $\mathrm{CD}(\mathrm{P}=0.05)$ & 1.80 & 0.52 & 2.68 & 71 & 141 & 226 & NS & 3213 \\
\hline \multicolumn{9}{|c|}{ B. Bio-fertilizers } \\
\hline Control & 19.23 & 6.54 & 34.46 & 926 & 1882 & 2808 & 33.13 & 34606 \\
\hline PSB & 24.01 & 7.18 & 37.29 & 1062 & 2114 & 3176 & 33.69 & 42047 \\
\hline VAM & 23.90 & 7.37 & 37.62 & 1039 & 2080 & 3119 & 33.51 & 40231 \\
\hline PSB + VAM & 28.15 & 7.92 & 40.38 & 1144 & 2281 & 3425 & 33.51 & 46087 \\
\hline $\mathrm{SEm} \pm$ & 0.62 & 0.18 & 0.93 & 25 & 49 & 78 & 1.13 & 1113 \\
\hline $\mathrm{CD}(\mathrm{P}=0.05)$ & 1.80 & 0.52 & 2.68 & 71 & 141 & 226 & NS & 3213 \\
\hline CV (\%) & 9.04 & 8.66 & 8.57 & 8.15 & 8.1 & 8.67 & 11.70 & 9.46 \\
\hline
\end{tabular}


Table.2 Effect of phosphorus fertilization and bio-fertilizers on N, P, K concentration, protein content and their uptake

\begin{tabular}{|c|c|c|c|c|c|c|c|c|c|c|}
\hline \multirow[t]{2}{*}{ Treatments } & \multicolumn{2}{|c|}{$\begin{array}{c}\text { N concentration } \\
(\%)\end{array}$} & \multirow{2}{*}{$\begin{array}{l}\text { Total N } \\
\text { uptake } \\
\text { (kg/ha) }\end{array}$} & \multirow{2}{*}{$\begin{array}{c}\text { Protein } \\
\text { content } \\
(\%) \\
\text { Grain }\end{array}$} & \multicolumn{2}{|c|}{$\begin{array}{c}\text { P concentration } \\
(\%)\end{array}$} & \multirow{2}{*}{$\begin{array}{l}\text { Total P } \\
\text { uptake } \\
\text { (kg/ha) }\end{array}$} & \multicolumn{2}{|c|}{$\begin{array}{c}\text { K concentration } \\
(\%)\end{array}$} & \multirow{2}{*}{$\begin{array}{l}\text { Total K } \\
\text { uptake } \\
\text { (kg/ha) }\end{array}$} \\
\hline & Grain & Straw & & & Grain & Straw & & Grain & Straw & \\
\hline \multicolumn{11}{|c|}{ A. Phosphorus levels (kg/ha) } \\
\hline Control & 3.08 & 1.42 & 46.46 & 19.25 & 0.352 & 0.166 & 5.38 & 0.765 & 1.617 & 31.36 \\
\hline 20 & 3.43 & 1.55 & 67.96 & 21.44 & 0.388 & 0.185 & 7.90 & 0.846 & 1.760 & 45.27 \\
\hline 40 & 3.65 & 1.67 & 81.69 & 22.81 & 0.415 & 0.199 & 9.53 & 0.899 & 1.864 & 54.25 \\
\hline 60 & 3.78 & 1.70 & 85.87 & 23.63 & 0.420 & 0.210 & 10.07 & 0.908 & 1.877 & 55.91 \\
\hline $\mathrm{SEm} \pm$ & 0.07 & 0.03 & 1.64 & 0.45 & 0.009 & 0.005 & 0.23 & 0.021 & 0.038 & 0.70 \\
\hline $\mathrm{CD}(\overline{\mathrm{P}}=0.05)$ & 0.21 & 0.10 & 4.74 & 1.31 & 0.026 & 0.013 & 0.66 & 0.061 & 0.110 & 2.03 \\
\hline \multicolumn{11}{|c|}{ B. Bio-fertilizers } \\
\hline Control & 3.14 & 1.43 & 56.67 & 19.62 & 0.347 & 0.166 & 6.41 & 0.757 & 1.641 & 38.25 \\
\hline PSB & 3.53 & 1.60 & 72.15 & 22.08 & 0.396 & 0.191 & 8.34 & 0.870 & 1.796 & 47.66 \\
\hline VAM & 3.48 & 1.59 & 70.05 & 21.77 & 0.397 & 0.187 & 8.11 & 0.867 & 1.789 & 46.65 \\
\hline $\mathrm{PSB}+\mathrm{VAM}$ & 3.79 & 1.71 & 83.11 & 23.66 & 0.436 & 0.216 & 10.03 & 0.923 & 1.893 & 54.23 \\
\hline $\mathrm{SEm} \pm$ & 0.07 & 0.03 & 1.64 & 0.45 & 0.009 & 0.005 & 0.23 & 0.021 & 0.038 & 0.70 \\
\hline $\mathrm{CD}(\overline{\mathrm{P}}=0.05)$ & 0.21 & 0.10 & 4.74 & 1.31 & 0.026 & 0.013 & 0.66 & 0.061 & 0.110 & 2.03 \\
\hline $\mathrm{CV}(\%)$ & 7.21 & 7.56 & 8.06 & 7.21 & 7.94 & 8.42 & 9.65 & 8.62 & 7.42 & 5.22 \\
\hline
\end{tabular}


Table.3 Effect of phosphorus fertilization and bio-fertilizers on phosphorus use efficiency and available phosphorus in soil after crop harvest

\begin{tabular}{|c|c|c|c|c|}
\hline Treatments & $\begin{array}{c}\text { Agronomic } \\
\text { efficiency of } P \\
(\mathrm{~kg} \text { grain } / \mathrm{kg} \mathrm{P})\end{array}$ & $\begin{array}{c}\text { Apparent recovery of } \mathbf{P} \\
(\%)\end{array}$ & $\begin{array}{l}\text { Physiological efficiency } \\
\text { of } P(\mathrm{~kg} / \mathrm{kg} \text { P) }\end{array}$ & $\begin{array}{c}\text { Available } \mathrm{P}_{2} \mathrm{O}_{5} \\
(\mathrm{~kg} / \mathrm{ha})\end{array}$ \\
\hline \multicolumn{5}{|c|}{ A. Phosphorus levels (kg/ha) } \\
\hline Control & - & - & - & 15.02 \\
\hline 20 & 3.23 & 12.59 & 103.22 & 17.10 \\
\hline 40 & 3.01 & 10.36 & 91.83 & 18.25 \\
\hline 60 & 2.67 & 7.81 & 91.28 & 18.35 \\
\hline $\mathrm{SEm} \pm$ & 0.07 & 0.25 & 2.09 & 0.35 \\
\hline $\mathrm{CD}(\overline{\mathrm{P}}=0.05)$ & 0.20 & 0.72 & 6.03 & 1.02 \\
\hline \multicolumn{5}{|l|}{ B. Bio-fertilizers } \\
\hline Control & 2.01 & 8.00 & 105.61 & 14.98 \\
\hline PSB & 2.24 & 10.41 & 93.03 & 17.60 \\
\hline VAM & 2.24 & 10.12 & 93.65 & 17.44 \\
\hline PSB + VAM & 2.42 & 12.49 & 89.47 & 18.70 \\
\hline $\mathrm{SEm} \pm$ & 0.07 & 0.29 & 2.41 & 0.35 \\
\hline $\mathrm{CD}(\overline{\mathrm{P}}=0.05)$ & 0.20 & 0.83 & 6.97 & 1.02 \\
\hline $\mathrm{CV}(\%)$ & 10.65 & 11.23 & 10.11 & 7.13 \\
\hline
\end{tabular}


The higher crop growth with more supply of phosphorus might regulate starch/sucrose ratio in source leaves and reproductive organs. The beneficial effect of phosphorus on fruiting of plants and better translocation of desired metabolites to the yield contributing parts of the plant might attributed to more grain yield. The improvement in straw yield might be due to the fact that phosphorus tends to increased growth and development in terms of plant height, branches and dry matter by improving nutritional environment of rhizosphere and plant system leading to higher plant metabolism and photosynthetic activity. These findings corroborate the results of Tanwar et al., (2003), Rathore et al., (2010) and Kumawat et al., (2013) in urdbean and Singh and Sekhon (2007) in mungbean. The application of phosphorus $40 \mathrm{~kg} / \mathrm{ha}$ recorded the significantly higher net returns (Rs. 47003/ha) over preceding levels and remained at par with $60 \mathrm{~kg} / \mathrm{ha}$. The increase in net returns might be due to higher grain and straw yield obtained under the treatment.

A significant increased protein content in grain, nitrogen, phosphorus and potassium concentration in grain and straw and their uptake were observed with the application of phosphorus upto $40 \mathrm{~kg} / \mathrm{ha}$ (Table 2). As stated that application of phosphorus might have nutritional environment in rhizospheric as well as in plant leading to increased uptake and translocation of nutrients especially of $\mathrm{N}$, $\mathrm{P}$ and $\mathrm{K}$ in reproductive structures which led to higher content and uptake. Further, the significant and positive correlation of yield with nutrients also evidenced for higher content of nutrients. Since, uptake of N, P and $\mathrm{K}$ is the function of grain and straw yield and their content, the significant increase in concentration of these nutrients coupled with increased grain and straw yield enhanced the total uptake of $\mathrm{N}, \mathrm{P}$ and $\mathrm{K}$. protein content is essentially the manifestation of $\mathrm{N}$ concentration in grain. Hence, increased $\mathrm{N}$ concentration might have increased the protein content. These results are close in conformity with the findings of Srinivasarao and Ali (2006) in urdbean and Kumawat et $a l$. , (2014) in greengram. Raising the level of phosphorus from 0 to $20 \mathrm{~kg} / \mathrm{ha}$ registered the highest agronomic efficiency, apparent recovery and physiological efficiency of phosphorus after that, it showed significant decline up to $60 \mathrm{~kg} / \mathrm{ha}$. Whereas, the available phosphorus in soil after crop harvest increased significantly upto $40 \mathrm{~kg} / \mathrm{ha}$ and remained at par with $60 \mathrm{~kg} / \mathrm{ha}$ (Table 3).

\section{Effect of bio-fertilizers}

Seed or soil inoculation with bio-fertilizers (PSB, VAM and PSB + VAM) significantly enhanced the number of pods/plant, number of grains pod-1, test weight as well as grain and straw yield of urdbean over no inoculation and no significant effect on harvest index (Table 1). The highest values of these parameters were recorded under combined inoculation with PSB + VAM that was accompanied by PSB and VAM, alone. This could be ascribed to the greater availability and uptake of phosphorus due to additive effect of these two bio-fertilizers in improving nutritional environment enhanced the growth in terms of branches and dry matter, photosynthetic area, production of assimilates and their translocation to reproductive structures, thereby increasing the yield attributes and ultimately, yield of the crop. Significant increase in straw yield due to bio-fertilizer inoculation could be attributed to the increased vegetative growth possibly as a result of effective utilization of nutrients absorbed through extensive root system and prolific shoot development on account of improved nourishment. These results are in close conformity with the findings of Biswas and Patra (2007) in greengram and Tomar et al., (2001), in urdbean. Dual use of PSB +VAM fetched significantly highest net 
returns (Rs. 46087/ha) in comparison to rest of the treatments. PSB and VAM also gave 16.2 and 21.5 per cent more return than control and thus found the next better and equally effective treatments.

Combined inoculation with PSB + VAM significantly enhanced the $\mathrm{N}, \mathrm{P}$ and $\mathrm{K}$ concentration in grain and straw, their total uptake as well as protein content in grain over untreated control (Table 2). The highest concentration and uptake were noted to be in PSB + VAM treated plots. This occurs due to increased solubilization and mineralization of organic phosphorus and availability of nitrogen and phosphorus (Kumar et al., 2014). Phosphorus concentration in soil after harvest of crop increased significantly due to inoculation with PSB + VAM. It might be due to build up of nutrients in soil. Dual inoculation of seed and soil with PSB + VAM recorded significantly highest agronomic and apparent recovery than rest of the treatments, whereas, the highest physiological efficiency recorded under control (Table 3).

\section{References}

Biswas, A. and Patra, A.P. 2007. Study on the effect of phosphorus, Vesicular ArbuscularMychorrhyza (VAM) and Phosphate Solubilizing Bacteria (PSB) on the performance of summer greengram. (In)National Symposium on Legumes for Ecological Sustainability: Emerging Challenges and Opportunities held during 3-5 Nov. 2007 at Indian Institute of Pulses Research, Kanpur.

Biswas, B.C., Das, S. and Subhash, K.P. 2001. Crop response to bio-fertilizers. Fertilizers News, 46: 15-24.

Gaur, A.C. 1991. Phosphate solubilizing micro-organism and bio-fertilizers. Omega Scientific Publishers, New Delhi, 176.
Kumar, S., Tomar, S. and Tomar, T.S. 2014. Integrated phosphorus management in blackgram (Vignamungo) in western utter pradesh during summer season. Annals of Agriculture Res., 5(3): 290297.

Kumawat, P.K., Tiwari, R.C., Golada, S.L., Garhwal, R.K. and Choudhary, R. 2013. Effect of phosphorus sources, levels and bio-fertilizers on yield attributes, yield and economics of blackgram (Phaseolusmungo) Legume Res., 36: 7073.

Kumawat, S.R., Khistriya, M.K., Yadav, S.L. and Kumar, M. 2014. Effect of phosphorus fertilization on yield, nutrient content, uptake and quality of summer greengram [Vignaradiata(L.) Wilczek]. Environ. Ecol., 32(2A): 785788.

Rathore, D.S., Purohit, H.S. and Yadav, B.L. 2010. Integrated phosphorus management on yield and nutrient uptake of urdbean under rainfed conditions of Southern Rajasthan, $J$. Food Legumes, 23(2): 128-137.

Sammauria, R., Yadav, R.S. and Nagar, K.C. 2009. Performance of clusterbean (Cyamopsistetragonoloba) as influenced by nitrogen and phosphorus fertilization and biofertilizers in Western Rajasthan. Indian J. Agron., 54(3): 319-323.

Singh, G. and Sekhon, H.S. 2007. Effect of sowing methods and fertilizer application on growth and yield of kharif mungbean (In) National Symposium on Legumes for Ecological Sustainability: Emerging Challenges and Opportunities, 3-5 Nov. IIPR, Kanpur.

Somani, L.L., Bhandari, S.C., Saxena, S.N. and Vyas, K.K. (Ed.) 1990. Biofertilizers. Scientific Publication, Jodhpur 142-145.

Srinivasarao, C.H. and Ali, M. 2006. Response of nutrient uptake of urdbean 
and mungbean genotypes to optimum nutrient supply on nutrient deficient sandy loam soil. Indian J. Pulses Res., 19(2): 259-262.

Tanwar, S.P.S., Sharma, G.L. and Chahar, M.S. 2003. Effect of $\mathrm{P}$ and biofertilizer on yield, nutrient content and uptake by blackgram (Vignamungo). Legume Res., 26(1): 39-49.

Tomar, A., Kumar, N., Pareek, R.P. and Chaube, A.K. 2001. Synergism among VAM, phosphate solubilizing bacteria and Rhizobium for symbiosis with blackgram (Vignamungo L.) under field conditions. Pedosphere, 11(4): 327-332.

\section{How to cite this article:}

Maya Yadav, S.S. Yadav, Sunil Kumar, Hansa Kumari Yadav and Pradip Tripura. 2017. Effect of Phosphorus and Bio-fertilizers on Yield, Nutrient Content and Uptake of Urban [Vigna mungo (1.) Hepper]. Int.J.Curr.Microbiol.App.Sci. 6(5): 2144-2151. doi: https://doi.org/10.20546/ijcmas.2017.605.240 